\title{
PLASMA HOMOCYSTEINE IN PATIENTS WITH CORONARY AND CAROTID ARTERY DISEASE: A CASE CONTROL STUDY
}

\author{
Marijan Bosevski ${ }^{1,5}$, Nenad Zlatanovikj ${ }^{2}$, Danica Petkoska ${ }^{1}$, \\ Atanas Gjorgievski ${ }^{1}$, Emilija Lazarova ${ }^{1}$, Lily Stojanovska ${ }^{3,4}$ \\ ${ }^{1}$ University Cardiology Clinic Skopje, Vascular Lab \\ 2 Private Medical Practice "Kor-Mediko", Skopje, R. N. Macedonia \\ ${ }^{3}$ Victoria University Melbourne, Australia \\ ${ }^{4}$ United Arab Emirates University, Al Ain, UAE \\ ${ }^{5}$ Faculty of Medicine, UKIM, Skopje, R. N. Macedonia
}

Corresponding author: Marijan Bosevski, Address: University Cardiology Clinic, 16 Vodnjanska Street, postal code: 1000, city: Skopje, country: N. Macedonia, Telephone number: 38972231135; E-mail: marijanbosevski@yahoo.com Marijan Bosevski and Nenad Zlatanovikj have participated equally in preparation of this paper.

\section{ABSTRACT}

Introduction: Homocystein (Hcy) is an amino acid and elevated plasma cause endothelial damage, followed with inflammation in the blood vessels and its progression in atherosclerosis. We aimed to evaluate the correlation between cardiovascular disease and serum homocysteine levels..

Methods: We performed a case control analysis of 212 patients, either for cardiovascular risk stratification or for invasive diagnostics and treatment of cardiovascular ischemic disease (CAD). Patients were divided into 4 groups: Group 1. Patients with low risk for CAD, with no symptoms of CAD and total of 10 years risk $<10 \%$. Group 2. High-risk patients with no symptoms of CAD, but 10 years total CAD risk of $>20 \%$. Group 3. Patients with symptomatic CAD, where angiography was performed and $>50 \%$ occlusion of at least one coronary vessel was found. Group 4 . Patients with carotid artery disease and documented CAD.

Results: Group 1 consists of 56 subjects, of whom 33 (60\%) males and $22(40 \%)$ females. Their mean age was $52.18 \pm 8.07$ years and their average CAD risk was 5 .

Group 2 included 60 patients, with average CAD risk of 23.73. There was a statistically significant difference between plasma homocysteine levels between the control and high CAD risk group, as well as between those with CAD and both CAD and CARD ( $\mathrm{p}=0.001)$. In the high-risk subjects group, the level of homocysteine correlates albeit weak with the total CAD risk $(\mathrm{p}=0.04)$. Homocysteine levels correlate with the WBC count $(p=0.02)$. In the subgroup of smokers with high CAD risk, homocysteine correlates with age, total CAD risk, total cholesterol, BUN (define BUN) and creatinine.

Group 3 consisted of 49 subjects with manifested and angiographically proven CAD, out of whom $80 \%$ were males and $20 \%$ females, mean age $56.06 \pm 9.7$ years, with average 2 coronary vessels affected. There were significantly higher homocysteine plasma levels between the control group and the group with manifested CAD ( $\mathrm{p}=0.008)$. There is no significant difference of homocysteine plasma levels between the high risk group and the group with manifested coronary artery disease $(15.03 \square \mathrm{mol} / 1 \mathrm{vs.} 16.38 \square \mathrm{mol} / \mathrm{l})$. In this group, plasma levels of homocysteine correlate only with the highest level of vessel stenosis $(>95 \%)$ with $(\mathrm{p}=0.04)$.

The study population in group 4 showed a mean of IMT $0.9+.09 \mathrm{~mm}$ and mean Hcy plasma levels of 21 $+11 \mu \mathrm{mol} / \mathrm{L}$. From the evaluated patients with CAD, $82.9 \%$ of patients had elevated level of Hcy. From those, one showed elevated Hcy, 79.4\% had hypertension, $58.9 \%$ had hyperlipidemia, $28.2 \%$ had diabetes mellitus as additional risk factors for atherosclerosis. $76.9 \%$ of the patients had increased intima-media thickness; in $58.9 \%$ plaques were detected, while $23 \%$ of the patients had significant stenosis: $10.2 \%$ with intermediate -grade stenosis (50-69\%) and $12.8 \%$ with high-grade stenosis (70-99 \%). $17.1 \%$ of the patients had normal level of Hcy, and in those ones $62.5 \%$ only had increased IMT. We found linear correlation between IMT and HCy levels (r 0.7, p 0.05). 
Case control analysis showed significant higher level of Hcy in the group with CAD and carotid artery disease vs. CAD group ( $\mathrm{p} 0.001)$.

Conclusion: High plasma homocysteine concentrations are associated with high risk for vascular disease and consequently CAD itself and carotid artery disease, as well, proving its likely role in the development of atherosclerosis on inflammatory and metabolic levels.

Keywords: Homocysteine, coronary artery disease, carotid artery disease, IMT, case control study

\section{INTRODUCTION}

In 1969 McCully published a description of vascular pathology in patients with homocystinuria for the first time, indicating a possibility that hyperhomocystinemia may be a cause for early coronary artery disease (CAD). That was the start of an idea to associate a CAD and homocysteine in patients with hereditary hyperhomocystinemia and homocystinuria, in whom an early and accelerated development of atherosclerosis was observed, with mortality rate up to $25 \%$ before the age of 30 .

From the beginning of the 1970s when the impairment of the methionine metabolism in patients with early and unexplainable coronary disease was described for the first time, there have been numerous studies, most of which confirm the role of homocysteine as an independent risk factor for development of coronary artery disease. Wald in a meta-analysis of 72 studies proved the relationship between increased levels of homocysteine as a result of mutation in the MTHFR gene with the increased risk for ischemic heart disease 1.32-1.42 folds, with deep vein thrombosis without pulmonary embolism 11.6 folds and with stroke 1.59-1.65 folds [2].

In the study on homocysteine and CAD risk in middle-aged men, after adjusting for other risk factors, the increased homocysteine levels $(>16 \pm \mathrm{mol} / \mathrm{L})$ contributed with $13 \%$ in the total CAD risk [1].

The ARIC study proved an increased CAD risk in hyperhomocysteinemic in males, but not in females [2]. In other studies the risk for CAD and stroke relationship to mortality was 1.9 to 2.8 [3].

Nygard did a follow-up on 567 patients with established CAD. Death risk was 1.9 bigger in those with tHcy $9-15 \pm \mathrm{mol} / 1$ and 2.8 for patients with tHcy $>20 \pm \mathrm{mol} / 1(4,5)$.

$\mathrm{HCy}$ has been defined as a novel risk factor for peripheral artery disease [6].
However, there is an ongoing debate if hyperhomocysteinemia is a biomarker, or a risk factor for CAD and CARD.

\section{MATERIAL AND METHODS}

In this case control analysis, 212 patients admitted to the University Cardiology Clinic, either for cardiovascular risk stratification or for invasive diagnostics and treatment of angina, acute coronary syndrome or acute myocardial infarction were followed. The study was performed according to the Helsinki declaration.

According to these criteria, patients were divided into 3 groups:

Group 1. Patients with low risk for CAD, with no symptoms of $\mathrm{CAD}$ and with total 10 years risk $<10 \%$.

Group 2. High-risk patients with no symptoms of CAD, but with 10 years total CAD risk of $>20 \%$.

Group 3. Patients with symptomatic CAD, where angiography was performed and a $>50 \%$ occlusion of at least one coronary vessel was found.

Group 4. Patients with carotid artery disease and documented coronary artery disease.

\section{Patients'evaluation}

Patients were evaluated using questionnaire, physical examination, laboratory tests and plasma homocysteine levels. A Chemiluminiscence assay was used for homocysteine analysis. The cutoff value for homocysteine was $>12 \mu \mathrm{mo} / 1$. Coronary artery disease was confirmed with angiography, which was performed in the cathlaboratory at the 
University Cardiology Clinic. Carotid ultrasound was used for determination of carotid artery disease which defines it as plaque or stenosis. Increased carotid IMT was measured as value $>0.08 \mathrm{~cm}$.

\section{RESULTS}

Group 1 consisted of 56 subjects, of whom $33(60 \%)$ were males and $22(40 \%)$ were females, with a mean age of $52.18 \pm 8.07$ years and average CAD risk of 5 .

All assessed factors of the control group are within the limits of the current AHA/ACC/ ESC guidelines.

Group 2 consisted of patients with high CAD risk. A total of 60 patients, of whom 38 (62.3\%) males and $22(36.7 \%)$ females, with average CAD risk of 23.73 were assessed. The lipid fractions within this group were significantly higher than in the control group.

There was a statistically significant difference between plasma homocysteine levels between the control and the high CAD risk group, as well between those with CAD and both CAD and CARD groups $(p=0.001)$ (Table 1).

Table 1. Differences in Homocysteine levels in the study groups

\begin{tabular}{|c|c|c|c|c|}
\hline & 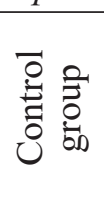 & 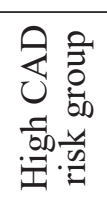 & 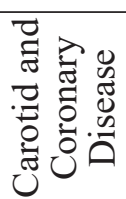 & $D_{1}$ \\
\hline 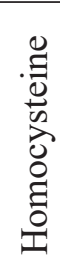 & 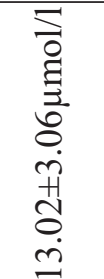 & 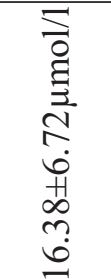 & $\begin{array}{l}\stackrel{\Xi}{\circ} \\
\stackrel{\Xi}{\Xi} \\
\Xi \\
= \\
+ \\
\vec{\sim}\end{array}$ & 官 \\
\hline
\end{tabular}

In the high-risk subjects' group, the level of homocysteine correlates albeit weak with the total CAD risk $(\mathrm{p}=0.04)$. Homocysteine levels correlated with the WBC count $(\mathrm{p}=0.02)$.

Other positive correlations in the high-risk group are presented in Table 2.

For more detailed analysis, this group was divided into subgroups: by sex and by smoking status. In the subgroup of males, homocysteine positively correlated with total CAD risk, total cholesterol, BUN and creatinine (Table 3 ).

In the female subgroup the homocysteine level positively correlated only with the WBC count ( $\mathrm{p}=0.02)$.

There are no statistically significant differences between the plasma levels of homocysteine between male and female subgroups.

In the subgroup of smokers with high CAD risk, homocysteine correlates with age, total CAD risk, total cholesterol, BUN and creatinine (Table 4 ).

Paradoxically, there is significantly higher plasma levels of homocysteine in the subgroup of non-smokers. In the non-smokers group, the levels of homocysteine correlates only with the WBC count.

Group 3 consisted of 49 subjects with manifested and angiographically proven $\mathrm{CAD}$, out of whom $80 \%$ were males and $20 \%$ were females, mean age $56.06 \pm 9.7$ years, with average 2 coronary vessels affected. Most of the lipid parameters were not significantly elevated due to already taking antihyperlipidemic therapy.

There were significantly higher homocysteine plasma levels between the control group and the group with manifested CAD $(\mathrm{p}=0.008)$ (Table $5)$. There is no significant difference of homocysteine plasma levels between the high risk group and the group with manifested coronary artery disease $(15.03 \pm \mathrm{mol} / 1$ vs $16.38 \pm \mathrm{mol} / \mathrm{l})$.

In this group, plasma levels of homocysteine correlate only with the highest level of vessel stenosis $(>95 \%)$ with $(p=0.04)$.

For more detailed analysis, this group was divided into two subgroups according to the smoking status.

There was a statistically significant correlation between plasma homocysteine levels between these subgroups. They also significantly differ in the number of CAD risk factors and the number of affected coronary vessels. In the subgroup of smoker homocysteine correlates with the gender $(p<0.05)$, while in the subgroup of non-smokers it relates with the age $(\mathrm{p}=0.036)$.

Study population in group 4 had a mean IMT $0.9+0.09 \mathrm{~mm}$ and mean Hcy plasma levels of $21+11 \mu \mathrm{mol} / \mathrm{L}$. From the evaluated patients with CAD, $82.9 \%$ of patients had elevated level of Hcy. From those, one with elevated Hcy, 79.4 $\%$ had hypertension, $58.9 \%$ had hyperlipidemia, $28.2 \%$ had diabetes mellitus as additional risk 
Table 2. Relation between Homocysteine and risk factors

\begin{tabular}{|c|c|c|c|c|c|c|c|c|c|c|c|c|c|}
\hline & 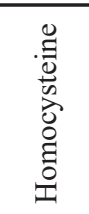 & 总 & 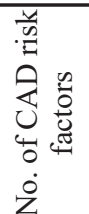 & 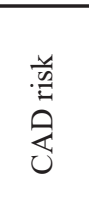 & 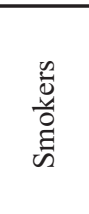 & 㒰 & 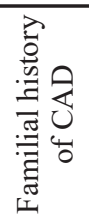 & $\begin{array}{l}\text { 感 } \\
\text { 点 }\end{array}$ & 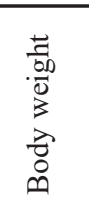 & $\sum_{m}$ & 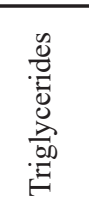 & 点 & 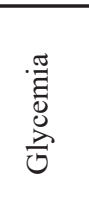 \\
\hline Age & & & & & 0.001 & & 0.011 & & & & 0.005 & & \\
\hline $\begin{array}{l}\text { No. of CAD } \\
\text { risk factors }\end{array}$ & & & & & & & 0.002 & 0.14 & 0.007 & 0.16 & & 0.004 & \\
\hline CAD risk & $* 0.46$ & & & & 0.023 & & & & & & & 0.029 & \\
\hline Smokers & & 0.001 & & 0.023 & & & & & & & & & 0.006 \\
\hline Hypertension & & & & & & & & 0.026 & & & 0.020 & & \\
\hline $\begin{array}{l}\text { Familial } \\
\text { history for } \\
\mathrm{CAD}\end{array}$ & & 0.01 & 0.002 & & & & & & & & 0.025 & 0.032 & 0.022 \\
\hline Stress & & & 0.014 & & & 0.026 & & & & & & & \\
\hline Body weight & & & 0.007 & & & & & & & 0.001 & & & \\
\hline BMI & & & 0.016 & & & & & & 0.001 & & & & \\
\hline Triglycerides & & 0.005 & & & & 0.020 & 0.025 & 0.28 & & & & & \\
\hline $\begin{array}{l}\text { Total } \\
\text { cholesterol }\end{array}$ & & & & & & & & & & & 0.028 & & \\
\hline WBC & 0.024 & & 0.004 & 0.029 & & & 0.032 & & & & & & \\
\hline Glycemia & & & & & 0.006 & & 0.022 & & & & & & \\
\hline BUN & & & & & & & & & & & & & 0.043 \\
\hline
\end{tabular}

Table 3. Correlation between Homocysteine and some risk factors in males

\begin{tabular}{|l|r|r|r|r|}
\hline & CADrisk & $\begin{array}{c}\text { Total } \\
\text { cholesterol }\end{array}$ & \multicolumn{1}{c|}{ BUN } & Creatinine \\
\hline Homocysteine & $\mathrm{p}<0.001$ & $\mathrm{p}=0.001$ & $\mathrm{p}=0.015$ & $\mathrm{p}=0.002$ \\
\hline
\end{tabular}

Table 4. Correlation between Homocysteine and some risk factors in smokers with high risk

\begin{tabular}{|l|c|c|c|c|c|}
\hline & Age & CAD risk & $\begin{array}{c}\text { Total } \\
\text { Cholesterol }\end{array}$ & BUN & Creatinine \\
\hline Homocysteine & $\mathrm{p}=0.024$ & $\mathrm{p}<0.001$ & $\mathrm{p}=0,043$ & $\mathrm{p}<0,001$ & $\mathrm{p}=0.014$ \\
& & & & & \\
\hline
\end{tabular}

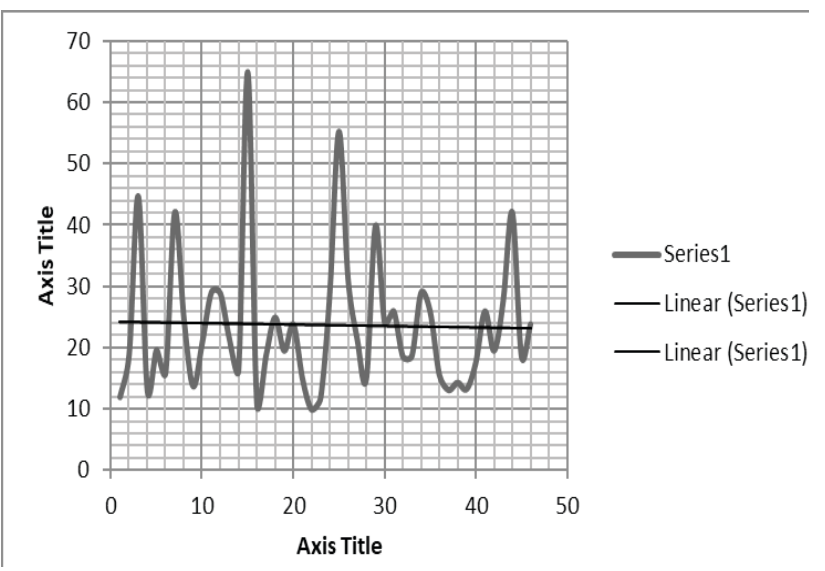

Figure 1. Distribution of Hcy value through 4th group

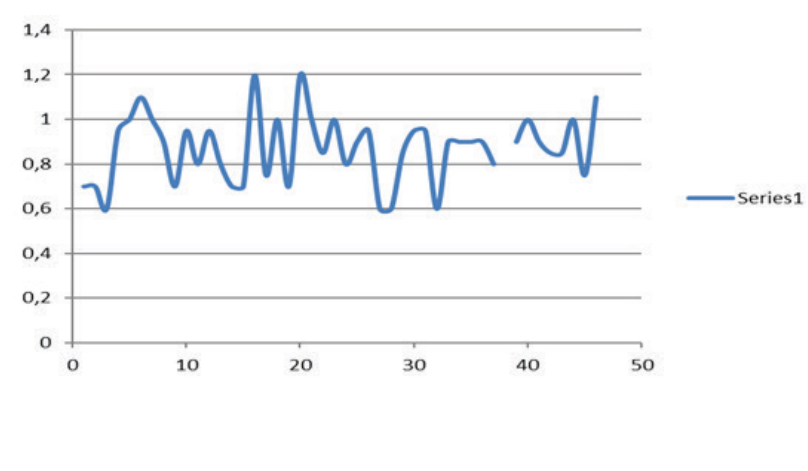

Figure 2. Distribution of IMT value through 4th group 
factor for atherosclerosis. $76.9 \%$ of the patients had increased intima-media thickness, in $58.9 \%$ plaques were detected, while $23 \%$ of the patients had significant stenosis: $10.2 \%$ with intermediate -grade stenosis ( 50-69\%) and $12.8 \%$ with high-grade stenosis (70-99\%). $17.1 \%$ of patients had normal level of Hcy, and in those one 62.5 $\%$ had only increased IMT. Distribution of IMT value and $\mathrm{HCy}$ was derived in Figures 1 and 2.

Patients with elevated levels of plasma Hcy had been related ( $\mathrm{r} 0.7 \mathrm{p} 0.0$ ) with increased IMT measured by carotid ultrasound. Plasma Hcy levels were significantly higher in pts with hyperlipidemia and diabetes mellitus.

\section{DISCUSSION}

In the PRIME study, published in 2007, on 323 subjects and 638 controls, total homocysteine levels were determined and compared to other risk factors. It was established that homocysteine is higher in smokers than in non-smokers $(\mathrm{p}=0.007)$. There is a positive correlation between homocysteine with smoking and CAD risk $(p=0.006)$ which confirms the synergistic action of homocysteine with old risk factors, and its undisputable influence on total CAD risk [12].

In the JACC study published on 39242 subjects in a follow up period of 10 years, it was concluded that stroke, myocardial infarction and total mortality from CAD are significantly higher in a group with tHcy $>15.3 \pm \mathrm{mol} / \mathrm{l}$. The risk was 4.35 high for stroke and 3.4 for myocardial infarction and 1.68 for total CAD mortality [10].

In the Study of Laraqi with 178 subjects, the aim was to establish a possible connection between homocysteine and $\mathrm{Lp} \mathrm{(a)} \mathrm{with} \mathrm{coronary} \mathrm{artery} \mathrm{dis-}$ ease. The study group had $>50 \%$ stenosis of the coronary vessels and the rest were controls. It was discovered that homocysteine was significantly higher in the study group, $8.26 \pm \mathrm{mol} / 1$ versus $17.85 \pm \mathrm{mol} / \mathrm{l}$. Surprisingly, this study did not reveal correlation with homocysteine and other risk factors. There was a weak correlation between tHcy and Lp (a) and both were independent risk factor for CAD [9].

Ranjith and all, in a study of 150 subjects, confirmed that increased homocysteine levels are independent risk factor for CAD, though no correlation with other risk factors was found [11].

In Ganguly's review of several studies concerning the role of homocysteine in the develop- ment of CAD, he concluded that most studies confirm homocysteine as an independent risk factor for CAD [7].

However, the study of Ghosh is one of the studies where he doesn't find any significant difference between homocysteine levels in the CAD and control group, therefore not being able to confirm any role of homocysteine in the development of CAD [8].

Yang et al, observational cohort study, in 2,919 Chinese participants, suggest that plasma level of homocysteine could increase the risk of developing advanced carotid artery plaques by $28 \%$ in the population aged above 40 [14].

The Northern Manhattan Study (NOMAS) was prospective, population-based cohort study with a unique race-ethnic distribution of community residents. In conclusion, elevated tHcy was independently associated with plaque morphology and increased plaque area and subclinical markers of stroke risk [13].

Selhub et al., performed a cross-sectional study of 1041 elderly subjects (418 men and 623 women; age range, 67 to 96 years) from the Framingham Heart Study, reported that the risk of developing $>25 \%$ extracranial carotid stenosis is increased 2-fold among elderly patients with elevated homocysteine levels and plasma concentrations of folate and pyridoxal 5' phosphate are inversely associated with carotid stenosis [15].

Boushey et al. [16]did a meta-analysis on 27 studies (up to early 1995) relating homocysteine to CVD and 11 studies on folate as a determinant of plasma homocysteine. Increased total homocysteine was an independent graded risk factor for CVD, with odds ratios of 1.6 and 1.8 for a 5 $\mu \mathrm{mol} / \mathrm{L}$ increment in men and women, respectively. A strong inverse correlation was found between total homocysteine and serum folate. A 5- $\mu \mathrm{mol} / \mathrm{L}$ tHcy increment elevates CAD risk by as much as cholesterol level increase of $0.5 \mathrm{mmol} / \mathrm{L}$.

Graham et al. [17] reported that increased total homocysteine was as strong as smoking and hyperlipidemia, as an independent risk factor for CVD on the basis of a large multicenter European study involving 750 cases and 800 controls.

In the Heart Outcomes Prevention Evaluation (HOPE), 2 trial of patients with diabetes or vascular disease, B-vitamin therapy significantly reduced stroke (by $25 \%$ ), but not myocardial infarction or death [7]. Homocysteine concentrations were measured in only $19 \%$ of participants after 5 years, and 
the reduction in homocysteine concentration was not statistically significant $[7,8]$.

Reduction of homocysteine levels has been most readily accomplished by supplementation of the diet with the $\mathrm{B}$ vitamins (folate, vitamins B6 and B12); reductions of up to $39 \%$ have been reported [5].Other therapies, including methionine restriction and exercise training, have also shown modest effects in reducing the levels of homocysteine [6].

The Limitation of our study is its design.

Our study confirms that there is a positive correlation between homocysteine levels and high risk for $\mathrm{CAD}$ and consequently $\mathrm{CAD}$ itself, proving its likely role in the development of atherosclerosis on inflammatory and metabolic levels. In our study homocysteine correlated with total CAD risk, WBC count, total cholesterol, BUN and creatinine. There is a significant difference between Homocysteine in pts with coronary and those ones with both coronary and carotid artery disease..

\section{REFERENCES}

1. WilckenDEL The pathogenesis of coronary artery disease. A possible role fo methionine metabolism. J Clin Invest, 1976; 57: 1079-82

2. Wald D, Law M, Morris J. Homocysteine and cardiovascular disease: evidence on causality from a meta -analysis. BMJ 2002 ; 325: 1202

3. Whincup PH, Refsum H, Perry IJ, Morris R, Walker M, L. Lennon, Thomson A, Ueland PM, Ebrahim BJ. Serum total homocystein and coronary heart disease: prospective study in middle aged men. Heart 1999; 82: 448-454

4. Ridker PM, Shih J, Cook TJ, ClearfieldM, Downs JR, Pradhan AD, Weiss SE, Gotto AM. Plasma homocystein concentration, statin therapy and risk of first acute coronary events. Circulation. 2002; 1055): 1776-9

5. Stubbs PJ et al. Effect of plasma homocysteine on early and late events in patients with acute coronary syndromes. Circulation, 2000; 102: 605-10

6. Norgren L, Hiatt WR, Dormandy JA, Nehler MR, Harris KA, Fowkes FG; TASC II Working
Group. Inter-Society Consensus for the Management of Peripheral Arterial Disease (TASC II). J Vasc Surg. 2007 Jan; 45 Suppl S: S5-67

7. Ganguly P, Alam Fatima S. Role of homocysteine in the development of cardiovascular disease. $\mathrm{Nu}-$ trition journal 2015; 14: 6

8. Ghosh Sh, Sanchita R, Soumitra K, Pritha P, Atreyee D, Ajantal H. Homocysteine- Is there any role in coronary artery disease? J. Cardiocascular disease research., 2017; 8(2): 46-49

9. Malinow MR et al. Homocysteine, diet and cardiovascular disease. A statement for health professionals from Nutrition Committee, American Heart Association. Circulation, 1999; 99: 178-82

10. Soinio M, Marniemi J, Laakso S, RonnemaaT. Elevated plasma homocysteine level is an independent predictor of coronary heart disease events in patients with type 2 diabetes. Ann Intern Med 2004; 140: 94-100

11. Ranjith R, Devika P. Clinical correlation between plasma homocysteine level and coronary artery disease in Indian patients. World journal of Cardiovascular disease 2017; 7: 477-485

12. J.A. TroughtonJ.V. Woodside I.S. Young D. Arveiler P. AmouyelJ. FerrièresP. DucimetièreC.C. PattersonF. KeeJ.W.G. YarnellA. Evans on behalf of the PRIME Study Group: Homocysteine and coronary heart disease risk in the PRIME study

13. Yang X, Zhou Y, Liu C, Gao X, Wang A, Guo Y, et al. Homocysteine and carotid plaque stability: a cross-sectional study in Chinese adults. PLOS ONE 2014; 9(4): e94935

14. Alsulaimani $\mathrm{S}$ et al. Elevated Homocysteine and Carotid Plaque Area and Densitometry in the Northern Manhattan Study (NOMAS).Stroke. 2013 Feb; 44(2): 457-461.

15. Selhub J et al. Association between plasma homocysteine concentrations and extracranial carotidartery stenosis. N Engl J Med. 1995 Feb 2; 332(5): 286-91.

16. Boushey CJ, Beresford SAA, Omenn GS, Motulsky AG. A quantitative assessment of plasma homocysteine as a risk factor for vascular disease-probable benefits of increasing folic acid intakes. JAMA 1995; 274: 1049-1057.

17. Graham IM, Daly LE, Refsum HM, Robinson K, Brattström L, Ueland PM, et al. Plasma homocysteine as a risk factor for vascular disease-the European concerted action project. JAMA 1997; 277: 1775-1781 
Резиме

\title{
ХОМОЦИСТЕИН ВО ПЛАЗМА КАЈ ПАЦИЕНТИ СО КОРОНАРНА И КАРОТИДНА АРТЕРИСКА БОЛЕСТ - АНАЛИЗА НА КОНТРОЛА НА СЛУЧАИ
}

\author{
Маријан Бошевски ${ }^{1,5}$, Ненад Златановиќ ${ }^{2}$, Даница Петкоска ${ }^{1}$, \\ Атанас Горгиевски ${ }^{1}$, Емилија Лазарова ${ }^{1}$, Лили Стојановска ${ }^{3,4}$ \\ ${ }^{1}$ Универзитетска клиника за кардиологија, Васкуларна лабораторија, Скопје, РС Македонија \\ ${ }^{2}$ Приватна установа Кор-Медицо, Скопје, РС Македонија \\ ${ }^{3}$ Викторија Универзитет Мелбурн, Австралија \\ ${ }^{4}$ Универзитет на Обединетите Арапски Емирати, Ал Аин, ОАЕ \\ ${ }^{5}$ Медицински факултет, УКИМ, Скопје, РС Македонија
}

Вовед: Хомоцистеинот е аминокиселина, чие покачено ниво во плазмата предизвикува оштетување на ендотелот, проследено со воспаление на крвните садови, а со тоа прогресија во атеросклероза. Целта на ова истражување е да се добијат податоци со кои би се докажала корелацијата меѓу кардиоваскуларните заболувања и нивото на серумскиот хомоцистеин.

Методи: Направивме case control study (студија на контрола на случаи), во која беа вклучени 212 пациенти или за ризик-стратификација на кардиоваскуларна болест или за инвазивна дијагностика и третман на кардиоваскуларна исхемична болест. Пациентите беа поделени во четири групи: во првата група беа пациенти со низок ризик за КАБ, без симптоми и 10 -годишен ризик $<10 \%$. Втората група ја сочинуваа пациенти со висок ризик, асимптоматски, но 10-годишен ризик за КАБ > $20 \%$. Трета групата - симптоматски пациенти за коронарна болест кај кои била направена коронарографија и наод за $>50$ \% стеснување на најмалку еден крвен сад. Четврта група - пациенти со каротидна артериска болест и докажана коронарна болест.

Резултати: Од обработката на податоците, во првата група беа вклучени 56 пациенти, од кои $33(60 \%)$ мажи и $22(40 \%)$ жени, со просечна возраст 52,18 $\pm 8,07$ просечен ризик за КАБ од 5.

Во втората група беа вклучени 60 пациенти, со просечен ризик од КАБ од 23,73. Имаше статистички значајна разлика меѓу вредностите на плазма хомоцистеинот со контролната и високоризичната група за КАБ, како и меѓу оние со КАБ и оние со комбинирана КАБ и КАРД $(\mathrm{p}=0,001)$. Во групата пациенти со висок ризик, нивото на хомоцистеинот, иако слабо, сепак, е во корелација со вкупниот ризик од коронарна болест $(\mathrm{p}=0,04)$. Нивото на хомоцистеинот беше и во корелација со бројот на леукоцитите $(\mathrm{p}=0,02)$. Во подгрупата на пушачи со висок ризик, хомоцистеинот е во корелација со возраста, вкупниот ризик од КАБ, вкупен холестерол, БУН и со креатининот.

Во третата група беа анализирани 49 пациенти со симптоматска и ангиографски докажана КАБ, од кои $80 \%$ мажи и $20 \%$ жени, средна возраст од 56,06 $\pm 9,7$ години, со просечно зафатени две коронарни артерии со сигнификантна стеноза. Значително повисоко ниво на хомоцистеин во плазмата имаше меѓу контролната група и групата со манифестна коронарна болест (p = 0,008). Немаше значајна разлика меѓу групата со висок ризик и групата со манифестна коронарна болест $(15,03 \mathrm{~mol} / \mathrm{l}$ vs. $16,38 \mathrm{~mol} / \mathrm{l})$. Во оваа група вредностите на хомоцистеинот се во корелација само со високостепена каротидна стеноза (>95\%) со ( $\mathrm{p}=0,04)$.

Популацијата од четвртата група беше со средна вредност на ИМТ $0,9+0,09 \mathrm{~mm}$ и средно ниво на хомоцистеин $21+11 \mu \mathrm{mol} / \mathrm{L}$. Од испитуваната група с одокажана коронарна болест, 82,9 \% од пациентите имале покачено ниво на хомоцистеин. Хипертензија имаше кај 79,4 \%, хиперлипидемија кај 58,9 \%, додека 28,2 \% дијабетес мелитус како дополнителен ризик-фактор за атеросклероза. Зголемена вредност на ИМТ имаше кај 76,9 \% од пациентите, кај 58,9 \% присуство на плаки, додека $23 \%$ од пациентите имаа значајна стеноза: 10,2 \% стеноза од среден степен (50-69 \%) и 12,8 \% од висок степен (70-99\%). Во 17,1 \% од пациентите со референтни вредности на хомоцистеинот, кај нив 62,5 \% имаа само задебелена ИМТ. Беше најдена линеарна корелација меѓу ИМТ и нивото на хомоцистеи (r 0,7, p 0,05). 
Контролните анализи на случаите покажаа значајно покачено ниво на хомоцистеин во групата пациенти со комбинирана КАБ и каротидна болест во споредба со групата само со коронарна болест (р 0,001).

Заклучок: Високото ниво на хомоцистеин во плазмата е поврзано со зголемен ризик од васкуларна болест, било коронарна или каротидна болест, со што, исто така, се докажува улогата во развивањето на атеросклерозата, предизвикана од инфламаторни и метаболни промени..

Клучни зборови: хомоцистеин, коронарна артериска болест, каротидна артериска болест, ИМТ, case control study 